\title{
Modern Settlements in Special Needs Education Segregated Versus Inclusive Education
}

\author{
Ratner, Helene
}

Document Version

Accepted author manuscript

Published in:

Science as Culture

DOI:

10.1080/09505431.2015.1120283

Publication date:

2016

License

Unspecified

Citation for published version (APA):

Ratner, H. (2016). Modern Settlements in Special Needs Education: Segregated Versus Inclusive Education. Science as Culture, 25(2), 193-213. https://doi.org/10.1080/09505431.2015.1120283

Link to publication in CBS Research Portal

\section{General rights}

Copyright and moral rights for the publications made accessible in the public portal are retained by the authors and/or other copyright owners and it is a condition of accessing publications that users recognise and abide by the legal requirements associated with these rights.

Take down policy

If you believe that this document breaches copyright please contact us (research.lib@cbs.dk) providing details, and we will remove access to the work immediately and investigate your claim. 


\section{Modern Settlements in Special Needs Education: Segregated Versus Inclusive Education Helene Ratner}

Journal article (Accepted version)

Cite: Modern Settlements in Special Needs Education : Segregated Versus Inclusive Education. /

Ratner, Helene. In: Science as Culture, Vol. 25, №. 2, २016, p. 193-213.

This is an Accepted Manuscript of an article published by Taylor \& Francis in Science as Culture on 15 April 2016, available online:

http://www.tandfonline.com/10.1080/09505431.2015.1120283

Uploaded to Research@CBS: November 2017 


\title{
Modern Settlements in Special Needs Education: Segregated versus Inclusive Education
}

\begin{abstract}
In the history of special needs education, the distinction between human nature and the social environment has been a controversial matter. The dispute regards whether special needs are caused primarily by the child's psycho-medical mind-body or by cultural concepts of normalcy and deviance. Settlements of this controversy govern whether the pupil or the educational institution is seen as the primary locus for intervention. In Denmark, the particularities of settlements can be identified by juxtaposing the introduction of intelligence testing in the 1930s with the contemporary policy agenda of inclusion. With intelligence testing, special needs education was to service children whose needs were seen as part of their human nature. Inclusion, in turn, assumes that 'special needs' is a stigmatizing cultural label, which needs to be abandoned by changing school cultures. Drawing on actor-network theory we can understand such settlement as the product of a modern division between human nature and social environment. Both settlements are characterized by practical tensions. These tensions include the practical difficulties in identifying 'pure intelligence' in the 1930s and the ambivalent status of special needs diagnoses in the contemporary focus on inclusion. More generally, juxtaposing intelligence testing with inclusion illustrates that special needs education bounces between modern poles of nature and society. This raises the wider question of how to theorize the consequences of modern settlements.
\end{abstract}

Keywords: special needs education, intelligence testing, inclusion, actor-network theory, modern settlements

\section{Introduction}

From the inception of special needs education, a distinction between human nature and the social environment has been a source of controversy. The question of whether special needs are congenital or rather an effect of the environment has always, in various forms, accompanied the term (Kirkebæk, 2010). It is now commonly recognized that special needs cannot be located exclusively in the individual or in society (Callon, 2008). Yet, a tension remains both in educational theory and policy between a view of special needs as primarily linked to the child's psycho-medical body and the view of special needs as mainly the effect of social and institutional conceptions of normality and deviance.

In this paper, I explore how different conceptions of special needs position the child and the educational institution as points of intervention. Instead of assuming the distinction between human nature and social environment, I will explore their joined enactment as a 'settlement', a contingent and partial explanation that enrolls collectives (Latour, 2005, p.129). This approach raises the following questions: How 
do conceptions of special needs education enact the modern distinction between human nature and social environment? How do settlements distribute cause and effect, problems and solutions to the pupil's mind/body or the social environment, respectively? Which practical tensions follow particular temporary settlements?

Denmark is an interesting site for exploring different conceptions of special needs education. Contemporary Danish special needs education is organized around idea of 'inclusion', which aims at educating almost all pupils with special needs in the ordinary primary school. This is to be accomplished by changing the current social learning environment, which is seen as containing barriers against inclusion.

I juxtapose inclusion with the introduction of intelligence testing in the Danish school system in the 1930s. Intelligence testing made it feasible to locate special needs such as 'imbecility' or 'backwardness' in human nature. This technique of sorting the 'deviant' from the 'normal' institutionalized the segregation of special needs education from normal education. It is this institutionalized segregation that inclusion seeks to unravel.

Both inclusion and intelligence testing enact a strong distinction between human nature and social environment; however, they do so in very different ways. This contrast illustrates the remarkable variations in how the modern distinction between human nature and social environment may be settled. Yet, it also showcases continuity in how tensions remain. Tensions become visible in the effort to purify human nature through intelligence testing and with the ambivalent status of special needs diagnoses in inclusion. We might understand these tensions as the result of ongoing modern efforts to purify (Latour, 1993).

The co-existence of psycho-medical and social conceptions of special needs calls for a symmetrical approach. Symmetry implies using the same vocabulary to describe all phenomena and abandoning an a priori distinction between the natural and the social (Callon, 1986). To this end, I use actor-network theory (ANT), and in particular Bruno Latour's (1993) characterization of the modern constitution. This approach offers an analytical sensitivity towards how distinctions between nature and society are made. This includes being sensitive to both the contingent status of nature and society and the remarkable efficiency they offer for imagining and organizing interventions in education. 
I use these insights to explore how different conceptions of special needs have implications for what counts as special needs and how professionals should relate to children believed to possess such needs. The underlying assumption of this paper is that different conceptions have ontological consequences for what special needs become. This means that I study the two versions of special needs education symmetrically, even if they are in conflict with one another. Both have effects. Even if inclusion is articulated as a critique of intelligence testing and its view of children (e.g. Thomas and Loxley, 2001), some tensions, as I will show, prevail across the two conceptions.

The paper proceeds as follows. After a brief introduction to the conceptual and empirical resources used in the paper, a short background section will introduce Danish special needs education. I then analyze the two settlements and their tensions. Obviously, the analysis comprises neither a complete understanding of the conceptions of special needs, nor a comprehensive historical account of special needs education in Denmark. For instance, recent psychiatric diagnoses such as attention deficit hyperactivity disorder (ADHD) and new categories of gifted and talented pupils are currently very important in the ongoing development of special needs education. My juxtaposition does offer, however, a deeper understanding of how special needs education bounces back and forth between the poles of the modern settlement.

\section{An Amodern Approach to Special Needs Education}

ANT emphasizes that 'society' and 'nature' are heterogeneous, distributed, multiple, and unfinished processes involving discourses, humans, and non-humans such as texts and technologies (e.g. Callon 1986, 196-223). Only through the association of 'actants', relatively stable networks and 'matters of fact' take form. This invites exploring the processes and means through which temporary fixation occur. What are some of the ideas, conceptions and technologies at play in stabilizations of special needs?

ANT assumes that nature and society are not different domains. In We have never been modern Latour (1993) explores their separation as the work of 'the moderns'. Using a jurisdictional metaphor of a constitution, Latour theorizes how EuroAmericans are able to live and think as if they were modern. Modernity, according to 
Latour, is premised on a contingent but powerful purification of nature and society. His diagram (1993, p. 11), illustrates the work of purification (separating nature from society) and the work of translation (producing hybrids) as two different processes, which reinforce each other.

The separation of the two processes is based on what Latour describes as the modern constitution's (paradoxical) 'guarantees'. One of these assurances is of particular importance to this paper: although nature is the result of contingent and heterogeneous construction processes (e.g. in laboratories), nature can simultaneously be seen as a transcendent reality waiting to be discovered by science (Latour, 1987). Conversely, whereas society obviously transgresses human will in so many ways, (e.g. when technologies shape human action) it also appears as if society is the construct of pure human force or will (Latour, 1993, p. 32). This guarantee elucidates that nature is enacted by the moderns as transcendent while society is enacted as a matter of human construction. It also highlights that although both these enactments are not given, they are very real in their consequences.

Latour's terminology is useful for analyzing conceptions of special needs as purifications, i.e. as simplified codings and explanations of complex matters (Brown, 2010, p. 117). It also highlights the partiality of purification. Indeed, Latour suggests that the work of maintaining the modern separation intensifies hybridization; the proliferation of networks across nature and society. In the analysis, I explore how the two different conceptions enact special needs as respectively a natural/ biological phenomenon and a cultural construction. This has consequences for what becomes the objective of intervention and in which ways. As such, the distinction between nature and society is highly political.

While Latour's idea of the modern constitution and its guarantees may seem rather abstract for an empirical analysis (Jensen, 2006), my analysis follows Latour's assumption that society and nature are not different ontological domains. Then I examine how different institutional practices separate the two through specific techniques and conceptual apparatuses. While my empirical material does not confirm Latour's idea of an intensified hybridization across modern separations, it does highlight practical tensions within each modern settlement. While I doubt that Latour would disagree with this point, the result of this analysis thus differs slightly how he conceptualizes the consequences of the modern constitution. 


\section{Methods}

The paper focuses on two different historical periods. For the purpose of analysing the modern settlement emerging with intelligence testing, I have read articles in the journal Folkeskolen ('the primary school'), published by the Danish Teachers' Association. Inspired by historians Christian Ydesen's (2011) and Bjørn Hamre's (2012) archival studies, I have mainly (but not exclusively) read articles by Henning Emil Meyer (1885-1967). Meyer was a key actor in the introduction and institutionalization of intelligence testing in Denmark (Bendixen, 2008). The articles studied range from 1928, when Meyer's early experiments with intelligence testing gained a central role in discussions in Folkeskolen, to 1943 when the Jewish Meyer fled due to the German occupation of Denmark (Ydesen, 2011, p. 16).

The analysis of the contemporary policy agenda of inclusion is based on a study of policy documents published primarily by the Danish Ministry of Education and Local Government Denmark. Empirical materials also include pedagogical literature mentioned in consultancy reports on how Danish municipalities work with inclusion (Jydebjerg and Hallberg, 2006; Zobbe et al, 2011). Furthermore, I have studied most of the Danish pedagogical publications on inclusion. The policy documents range from 1994 when Denmark signed the Salamanca Statement (international framework for inclusive education) to 2012. The analysis also draws on interviews made during fieldwork at two Danish schools in the period 2009-2012.

While document analysis obviously does not offer a direct representation of practice, the sources I analyze were central to the pedagogical community in both periods. As such, they circulated and performed 'authorizing accounts' (Smith, 1978) of special needs education. In that respect, we might think of documents as 'material-semiotic actors' (Jensen and Lauritsen 2005), emphasizing both their materiality (how they circulate) and their semiotics (how they produce meaningful communication). My analysis focuses on the latter.

As a starting point I investigate how the texts from the two periods express distinctive conceptions of special needs and hence exemplify its different enactments. I have paid attention to how purification takes place (e.g. how the intelligence test became a 'spokesperson' (cf. Callon, 1986) for a purified nature) and to articulations of distinctions human nature and social environment. In the analysis I ask how certain 
techniques and conceptions make it is possible to enact the modern distinctions. I also look for attributions of cause and effect across human nature and social environment, e.g. what was considered the cause of special needs and what interventions this suggested. The practical tensions are a result of this analysis.

\section{Background}

To situate the two examples, I will briefly introduce the Danish history of special needs education. Concurrent with the establishment of a national public school during the $19^{\text {th }}$ century, practices of sorting children according to their abilities developed and remedial schools were established. This sorting occurred without national legislation or established nationwide remedial procedures (Coninck-Smith, 2000). The first special institutions were private and admitted so-called idiotic, imbecile and epileptic children (Coninck-Smith, 2000; Ydesen, 2011). The public school soon followed suit, instituting protected classes (værneklasser) for so-called retarded and mentally handicapped pupils.

It was not until the introduction of the intelligence test, which I will look into in the first analysis, that methods for selecting pupils for segregated education were systematized. The entrepreneurial teachers and psychologists who introduced intelligence testing in the 1930s also established educational psychology as a new kind of expertise for sorting pupils into remedial education according to their IQnumber (Bendixen, 2008; Ydesen, 2011). This arguably contributed to the institutionalization and growth of segregated special needs education.

In 1937, segregated special needs education was embedded in the Primary Education Act, and in 1943, a government circular introduced categories such as deficiency in intelligence and visually impaired. In 1958, the establishment of special needs education became a legal requirement. The number of segregated special needs education activities grew and so did the relative number of pupils involved. (Egelund, 2004; Danish Ministry of Finance, 2010).

During the 1960s the first critiques of special needs education emerged. Critics questioned to what extent segregated special needs education had any effect and whether segregation was actually the cause of the deviant 'careers' it was supposed to remedy. In 1968, for example, a Danish report concluded that 'supportive learning environments' in the ordinary school were more helpful for pupils with special needs 
than segregated reading classes. This suggested that segregation was not necessary in order to educate pupils with special needs (Tordrup, 1968). At this point, the term segregation ('adskillelse' or 'udskillelse' in Danish) started to lose its neutral tone. Instead, it was increasingly viewed as marginalizing and stigmatizing.

As described in a report on special needs education by the Danish Ministry of Finance (2010), the 1970s involved a fundamental shift: the concept of special needs was generalized from primarily encompassing pupils diagnosed with physical disabilities and poor scholastic skills to include their general social and psychological capacities (p. 40). For example, the Primary Education Act of 1975 defines that special needs education is for 'children whose development needs a special consideration or support'. This further increased the number of referrals to special needs education (ibid). ${ }^{\text {i }}$

Today, the concept of special needs is both flexible and contested. It encompasses 'mental' and 'physical' conditions but also unspecified norm-breaching behaviour. Special needs diagnoses such as attention deficit hyperactivity disorder (ADHD) are frequently criticized for producing problematic boundaries between normal and deviant behaviour (Conrad, 1975; Singh, 2008), whereas others, for instance speech impairment, rarely spark controversy. Moreover, the demarcation of special educational needs is fluid as problems considered 'social', e.g. parental neglect, can materialize in 'psychological' issues.

\section{The Modern Settlement of psycho-metric testing}

In 1934, Frederiksberg municipality, located in Copenhagen, Denmark, employed the local public school teacher Henning Emil Meyer as the first Scandinavian educational psychologist. As Ydesen has convincingly argued, Frederiksberg came to serve as an example for other Danish municipalities prior to the establishment of a specialized training course at the University of Copenhagen in 1944, which institutionalized educational psychology as a profession (Ydesen, 2011, p. 54). While intelligence testing has been the subject of much critique especially since the 1960s (and the concept of intelligence itself has changed a lot since then), it is still central to contemporary educational psychology (Bendixen, 2008).

Prior to his employment in Frederiksberg, Meyer had conducted an extensive study of sorting practices in primary schools. He documented that up to $35 \%$ of all children 
lagged behind their classmates, hence questioning the existing practices of segregation, which relied directly on assessments made by teachers and school doctors (Ydesen, 2011, p. 47). Meyer noted that the sorting practices were characterized by 'misunderstandings', 'difficulties', and 'lack of clarity' (Meyer, 1929, p. 697). ${ }^{\text {ii }}$ As an alternative Meyer suggested using psychometrics, a Danish standardized version of the French Binet-Simon intelligence test developed in 1905 for selecting children for remedial education (Binet, Simon \& Drummond, 1914; Egelund, 2004, p. 39). ${ }^{\text {iii }}$

Referring to the intelligence testing as a scientific method, Meyer criticized existing practices as non-scientific. Intelligence testing provided a number, an intelligence quotient score (IQ) to represent the pupil's intelligence. With ANT we can think of intelligence testing as an inscription device: 'The invisible [intelligence] becomes visible and the 'thing' becomes a written trace they can read at will as if it were a text' (Latour, 1983, p.163). As a number inscribed on paper, it is both mobile and immutable, lending the heterogeneous network (Callon, 1987) around intelligence testing stability and durability.

Within a few years, the IQ-number became indispensable in educational sorting practices in Frederiksberg. Its numerical valuation of intelligence offered a clear way of settling which kind of education each pupil should receive. Johannes Søegaard, a Danish headmaster much involved in the discussions of intelligence testing, noted how the IQ number enabled dividing pupils into 'brilliant' (above 100), 'normal' (100), and 'below normal' (70-90) (Søegaard, 1939, 415). IQ was further used to distinguish between degrees of idiocy, and in Frederiksberg the intelligence test became mandatory if a pupil was referred to segregated special needs education (Ydesen, 2011, 105). In the following, I will explore how the test produced a particular settlement of the relationship between human nature and social environment and I will discuss the tensions that followed the settlement.

With considerable inspiration from English educational psychologist Cyril Burt and Canadian psychologist Peter Sandifort, Meyer argued for using primarily (but not exclusively) two kinds of test: intelligence tests and scholastic tests [standpunktsprøver]. 
While intelligence tests measure the child's congenital abilities... without taking into consideration the proficiency and skills obtained through systematic teaching, the scholastic tests will precisely measure the child's progress in the general school proficiency and skills (Meyer, 1929, p. 698).

In Meyer's view, scholastic skills reflected what the child had learned in school, while the IQ number revealed the innate intelligence, uncontaminated by external influences. The former made something explicit about the social environment whereas the IQ number represented human nature.

This distinction between scholastic skills and intelligence has implications. For Meyer, intelligence was crucial as it conditioned 'to which degree a child can learn' (Meyer, 1929, 682). Meyer thus considered intelligence primary to scholastic skills. Together, the two tests enacted a distinction between the child's innate intelligence, which presumably could not be changed, and the social environment, the education endowing the pupil with specific scholastic skills. Yet, he positioned intelligence as the decisive aspect of a pupil's learning trajectory.

This distinction between human nature and social environment is an instance of Latour's (1993) depiction of modernity's distinction between nature and society. The distinction entails a particular settlement: Intelligence, an expression of human nature, became seen as fixed, innate and as distinct and distinguishable from scholastic skills. Scholastic skills, in turn, were seen as changeable insofar as the pupil's intelligence allowed for this.

This settlement distributed both causes and responsibilities. Meyer argued that a comparison of the two test results was important for deciding what kind of intervention to make: if a low IQ matched a low scholastic level, then the latter was due to the child's innate intelligence and little could be done. But if the IQ was markedly higher than the scholastic test results, this should trigger an investigation of how to remedy the scholastic capabilities of the child (Meyer, 1929, p. 682).

Meyer considered the IQ test an objective technique for assessing children's congenital and unchangeable intelligence. A contemporary headmaster advocating intelligence testing reflects the belief in discovering congenital intelligence through testing: 'With a battery of different tests, a teacher should be able, with no prior 
knowledge of the pupils, to decide their intelligence and class them with that group or type to whom he or she naturally belongs’ (Jørgensen in Hamre, 2012, p. 109).

Intelligence testing was thus considered an apt tool for segregated education.

In contrast to current critiques of intelligence testing as stigmatizing (e.g. Bendixen 2008), Meyer argued that IQ testing and segregated education would make the educational system more just, for pupils and teachers alike. Several of his articles include engaging narratives about children who have been saved by the 'right' educational measures after psychometric assessment.

One story involves a juvenile delinquent, believed to be idiotic [åndsvag] and unfit for education until an intelligence test proved this to be a misconception. As a consequence of his test results, the boy was spared from regular punishment and was granted an education instead. The boy became a good law-abiding citizen and Meyer concluded: 'Think about it! If this boy had really been treated like an idiot! What life would he not had led! Crime upon crime, punishment upon punishment! (...) Instead, the psychological examination proves that he is far from idiotic' $(1929$, p. 715$)$.

Other spellbinding examples involve 'backward' pupils with 'normal intelligence' where a mismatch between their scholastic performance and their IQ led teachers to explore why they underperformed. The reasons identified were often poverty and poor parenting skills (because of alcohol abuse for instance) but illness or poor nutrition during childhood were also sometimes used to explain the mismatch. In one case, a girl's high consumption of coffee was identified as the cause of sleep deprivation. Such 'social' issues were considered malleable. While children's 'deviance' could be attributed to both social and biological factors, the latter was still ascribed the primary explanatory power. Only when the intelligence test indicated that a child ought to perform better scholastically would the teachers begin to look for explanations in the child's environment.

Teachers, according to Meyer, would also benefit because they would not to the same degree be held accountable for their pupils' scholastic test results:

The teachers are themselves eager to generate 'good' results - but a 'bad' result can very well be 'good' when understood in relation to the foundation the teacher has had available. Imagine how education and teaching would change if we truly acknowledged the influence of non- 
variable factors [intelligence], how pushing and tormenting, scolding and punishing (...) would disappear (Meyer 1929, 683).

By characterizing intelligence as 'non-variable', Meyer reduced the range of impact that teaching could have. The quality of teaching was made relative to the 'foundation', the pupil's innate intelligence. Following this, Meyer argued that teachers should no longer be held accountable for their pupils' general performance. Instead, teachers' skills should be assessed in relation how well the pupils' scholastic skills and their IQs corresponded.

Meyer further advocated a differentiated teaching approach in which teachers, using the test results as foundation, should accommodate their teaching to individual pupils' intelligence. Intelligence testing, in other words, was to settle questions of how much a teacher could expect from a pupils' performance. As a consequence, intelligence testing was granted the potential to revolutionize the education system by systematizing segregation and changing teaching interventions to the benefit of both pupils and teachers.

These examples illustrate how the intelligence test's enactment of the distinction between human nature (intelligence) and social environment (teaching) also settles where and how to intervene. The juvenile delinquent's high intelligence proved him fit for education - thus, 'society' (i.e. the education system) could shape and change him into a law-abiding citizen. And reversely, if intelligence was low and the pupil's 'scope of development is narrow', as Meyer put it elsewhere $(1929$, p. 834), the education system could not be held accountable.

Intelligence testing was seen as a method for gaining scientific access to human nature, the true intelligence residing in the child, which could not be changed by human intervention. In spite of the differentiation between scholastic skills and intelligence, intelligence testing was also deemed to be more accurate than examinations and grading. At the time, these were increasingly viewed as subjective teacher evaluations, compared to the IQ test (Bendixen, 2008).

Educational psychologists established themselves as a profession equipped with the right tools to read each child's level of intelligence and to categorize everybody in the right way. Testing became prevalent because it was accepted as the status of a pure and objective method. Yet, several 'social' matters also influenced intelligence 
testing. Finances, for instance, may have had an impact on the formation of IQ intervals. As such, the decision that an IQ between 70-90 would point to the need for remedial education was related to how much of such education Frederiksberg could afford at the time (Ydesen, 2011, p. 59, 88).

\section{Tensions}

The very idea of a pure intelligence created a number of tensions in the practical work of measurement (Ydesen, 2011, 98). Meyer described the intelligence test as a measure of intelligence independent of skills acquired through schooling. Yet, he consecutively stated that 'it will never be possible to measure the pure intelligence, so to speak, but only to measure the natural abilities and the surroundings in which the child grows up' (Meyer, 1926, p. 38). The impossibility of reproducing in practice the theoretical distinction between pure intelligence as an expression of human nature and everything else learned in a social environment generated new forms of differentiation. The social environment was further divided into teaching originating from the school, which could be measured, and teaching emerging from a more unspecified notion of surroundings, which influenced the intelligence test. In that way, the division of labour between intelligence tests and scholastic tests could continue.

Meyer also conducted 'failed' experiments with intelligence testing. One experiment tested whether the intelligence test was a better means for selecting pupils for intermediate school than the judgment of teachers (Meyer, 1932). Meyer concluded that characteristics such as 'interest', 'endurance', 'conscientiousness', and 'hard work' were more important than high intelligence, and that 'one does not need an overwhelming high intelligence to pass the intermediate school' (1932, p. 390). This failed experiment, however, did not make the intelligence test superfluous, he claimed: An intelligence test could still help teachers assess pupils by identifying whether intelligence or hard work was the cause of pupils' scholastic skills (ibid). A final tension regards the status of the intelligence test: To what extent did it constitute knowledge of the child? Should one also include 'social' aspects? While Meyer (1932) described psychometric testing as 'precise' and 'objective' (p. 388), he also emphasized that the scholastic and intelligence tests should never be the only methods for gaining knowledge of the child. For instance, pupils' 'hard work', 
'mental endurance', 'sense of duty', and 'enthusiasm' could to some extent compensate for a lower intelligence and Meyer recommended to include teachers' evaluations of such qualities (p. 390).

Ten years later, Meyer (1943) repeated the argument that tests could not be the sole means for assessing children. He emphasized the need for having 'a conversation with one of the parents, through which the psychologist tries to obtain as much information as possible about the child' (p. 603). This should include physical information about birth, first nutrition, teething, walking, speech, illness; information about play and family circumstances such as deaths, divorce and the economic situation at home (ibid). Many issues that could not be located strictly within the child had to be taken into consideration.

However, Ydesen (2011) examined Meyer's records and evaluations of children and concludes: 'in the majority of his endorsements, Meyer mentioned the result of the intelligence test as the sole determining factor' (p. 107). The practical problems with purifying intelligence from contaminating social factors, it appears, did not challenge the general view of the intelligence test as a reliable spokesperson (cf. Callon, 1986) for human nature. It maintained a high status compared to the other sources of information in justifying and deciding what kind of (special needs) education a child would receive.

\section{Inclusion: Reassembling the relationship between human nature and social environment}

The recent turn to inclusive education challenges the modern settlement achieved with intelligence testing in the 1930s. Inclusion brings about a new modern settlement that also effectuates a strong distinction between human nature and social environment. This time, however, special needs are primarily seen as social constructs residing in the social environment and not as a human trait in individual children. As in the former case inclusion also generates specific tensions.

Many scholars trace inclusion back to 1994 when delegates from 92 countries and 25 international organizations congregated at a UNESCO conference in Salamanca in Spain to promote education for all (UNESCO, 1994). The conference resulted in the Salamanca Statement, which declares that all children should have equal access to the ordinary school, which, in turn, should accommodate to pupils with special needs by 
applying a pedagogy with focus on the individual. Advocates for inclusion depict the Salamanca Statement as a radical 'paradigm shift', involving a 'new ethics' which affirms that all pupils are equal and that diversity is a resource (Thomas \& Loxley, 2001; Sebba and Sachdev, 1997; Ainscow, 1995). These advocating scholars often assert that 'the normal pupil' and 'the pupil with special needs' are stigmatizing social categories rather than scientifically discovered medical phenomena (see also Oliver, 1986; Tomlinson, 1987; Barton, 1987; Skrtic, 1991).

The move towards inclusion - and the critique of special needs education - is linked to social movements in the 1960 s and 1970 s seeking to replace a 'medical model' of disability with a 'social model' (see Galis, 2011). Here, I will look at how contemporary policy documents and Danish educational psychologists have problematized segregated special needs education with the idea of inclusion. As in the former section, I will explore how inclusion articulates a distinction between human nature and social environment and related tensions.

Many contemporary scholars define inclusion in opposition to what they see as a segregating 'paradigm of integration', a paradigm that seeks to integrate pupils with special needs in the ordinary school without questioning the stigmatizing effects of the category of special needs (Thomas \& Loxley, 2001). Designating inclusion as a separate paradigm entails the renegotiation of the concept of special needs. Instead of scrutinizing the pupil's psycho-medical body and mind, inclusion is based on the idea that specific concepts and teaching practices stigmatize pupils who are labelled as deviant.

In this view, special needs education is problematic because as a practice it contributes to the segregation of exactly those children it seeks to help. In the 1930s, the emerging profession of educational psychology saw segregated education as the best way to address special needs. With the idea of inclusion, however, segregated education is considered stigmatizing and for that reason as something to be avoided. Inclusion thus entails far more than retaining pupils with special needs in the ordinary primary school: pedagogues, teachers and educational psychologists are encouraged to rethink their concepts of normality and question problem-solution constellations at play in special needs education. 
In Denmark, the contemporary focus on inclusive education materializes through a statistical apparatus, policy making, municipal projects, conferences, websites, networks, and new knowledge institutions (Ratner, 2012). Governmental educational statistics, for instance, now produces detailed data on inclusive and segregated education (Bækgaard and Jakobsen 2011:7). New institutions with specialized expertise in inclusion have also emerged during the 2000s. In 2005 the National Centre for Knowledge about Inclusion and Exclusion was established, in order to 'systematically accumulate and develop knowledge' (NVIE) about inclusion and exclusion in pedagogical practices (National Centre for Knowledge about Inclusion and Exclusion, 2012). This enactment of 'systematic' and 'rigorous' knowledge on inclusion challenges the existing hegemony of psychological and medical expertise in special needs education.

Institutions such as NVIE often circulate the idea that organizational cultures and professional mindsets are the main obstacles to realizing inclusion (this is also the case internationally, see for instance Avramidis \& Norwich, 2002; Reid, 2005, p. 100106). In Denmark, this focus on the institutional environment appeared in educational policy in the 2000s. In their 2003 publication, The Inclusive School: From Idea to Action, the Danish Ministry of Education characterizes inclusion as 'a confrontation with the practice of segregating pupils from the normal teaching environment and a [new] focus on how segregation can be a kind of action that secures the survival of a certain teaching tradition' (2003). This shifts the aim of intervention. 'Teaching traditions' with stigmatizing effects need to be changed, rather than pupils assumed to have special needs.

In the same publication, the ministry asserts that for headmasters and teachers to adapt to the inclusive 'educational paradigm', they need 'continuous reflection on their own practice and the school's role in society' (Danish Ministry of Education, 2003, p. 111). Inclusive special needs education is a matter of how teachers' adapt to a paradigm rather than using accurate diagnostic tools, as we saw with intelligence testing. This enacts a new way of making the distinction between human nature and social environment where the latter must be constantly scrutinized for its potentially stigmatizing effects. In this view, special needs are no longer primarily located in the pupil's psycho-medical body but linked to teaching traditions and practices. 
Several Danish psychologists articulate this distinction between human nature and the social environment. Jens Andersen, for example, writes that inclusion is primarily about a given teacher's 'personality, view of human nature, perception of normality, perception of deviance, professional universe, [and] explanations' (2009, p. 9). Søren Langager claims that 'it is the teachers' attitudes and expectations that really determine where children and young persons end up in the social hierarchy within the school and the educational system,' (2004, p. 115). As a final example, psychologist Rasmus Alenkær, frequently cited in local governments' strategy papers on inclusion, states: '[Inclusion is] a process where one continuously relates reflectively to oneself and scrutinizes how to meet the pupils as opposed to employing a rigid template' (Alenkær 2009:21).

At present, this mode of conceptualizing special needs is widely recognized and applied. A best practice study financed by the Ministry of Education found that municipalities consider teachers' vocabulary and attitudes the most important factor in promoting inclusion: '[that the teacher is] conscious about his or her co-constructive language, i.e., being attentive to how the pupil group is talked about [and] ... focuses on the good things rather than fault finding' (Zobbe et al., 2011, p. 8-9). The report further summarized the municipalities' understanding of pupils' individual challenges as emerging 'from the structure in society and from interactions between persons' (ibid, p. 90).

This implies a different settlement than intelligence testing in the 1930es. Seen as objective diagnosis it could guide how education was to be segregated. Teachers were expected to reflect and intervene if a gap was discovered between how a pupil performed in intelligence and scholastic tests. The tests, thus, articulated to what extent pupils' deviance was environmental (and changeable) or congenial (and unchangeable).

With inclusion, however, any deviance points back to the social environment, and mainly to teachers' attitudes, expectations and values. As a consequence, teachers are now expected to make their expectations and norms explicit and to critically examine how they co-produce deviance. Curiously, this swaps the pupil for the teacher as the object of intervention. The pupils' behaviour reflects whether the teacher's practice is including or excluding. 
The redefinition of special needs as a cultural and contingent phenomenon rather than as a natural and scientific one enacts a different modern settlement (Latour, 1993). This settlement redistributes responsibilities and produces new opportunities for intervention. Once special needs are seen as socially constructed artifacts, practitioners become responsible for the (social) constructions of the pupil with special needs. This further problematizes the concept of special needs and the associated psychological and medical forms of diagnosis: they are no longer seen as forms of objective knowledge but as knowledge embedded in professional knowledge practices with a dubious scientific epistemology (e.g. Thomas and Loxley, 2001).

Inclusion entails the diagnosis of educational practices and various categories that construct special needs. Reflection becomes part of a deliberate, instrumental, constructivist politics aimed at changing norms and practices. As anthropologist Bill Maurer writes, the 'apparent consensus that "everything is constructed"...is accompanied by the moral imperative that we can and must construct those worlds at will' (Maurer, 2005, p. 165).

\section{Tensions}

In one sense, the inclusion settlement appears to be the inversion of what happened 70 years earlier. This time, humans are granted the power to construct society by changing their categories. The modern settlement continues, but the power of nature has been swapped for the power of society (Latour, 1993). In another sense, however, inclusion is not free from tensions. As I will show, these tensions might re-introduce the idea of authentic special needs in inclusive special needs education.

In the body of literature that I discussed in the previous section, the idea of inclusion relies on a (instrumental) social constructivist epistemology that places the potential for change in mouldable cultural values and categories. As a consequence, inclusion is, theoretically speaking, limitless, as all (stigmatizing) categories, located in teachers' mindsets and teaching traditions, can be changed (Hansen, 2012).

This version of special needs does have some purview among practitioners. In an interview with me, a municipal education director, for instance, expressed the view that special needs is a matter relative to how teachers talk about pupils: 'Well, I'm not impressed when I hear teachers claim that they have included four pupils in their group. That's a very stigmatizing statement' (interview, 2012). Despite the inclusion 
literature's explicit focus on the performative effects of categories, the director suggests that inclusion also generates new stigmatizing categories. Some pupils become visible as 'included' in contrast to a majority whose inclusion/exclusion is not addressed.

This enacts a contrast between special needs as an authentic characteristic, which can be accommodated through inclusive teaching (as the teachers' claim), and special needs as a label that stigmatizes (the municipal director's claim). Even with an inclusive approach, the idea of authentic special needs may be attractive as diagnosis offers an explanation to parents and teachers who deal with uncomfortable 'deviant' behavior (Brown 2010:16). Yet, as the municipal director also illustrates, one interpretation of inclusive education abandons the very distinction between 'special' and 'normal' as these are seen as stigmatizing categories.

This tension reappears in the relation between special needs education and teaching differentiation. Teaching differentiation is a teaching philosophy, which claims that teachers must accommodate their teaching in appreciation of the needs and learning potentials of individual pupils. Rather than a 'one size fits all' model, the principle of teaching differentiation (introduced in the Danish primary school legislation in 1993) commits the teacher to target his teaching at individual pupils' particular conditions for learning.

Teaching differentiation is often articulated as central to inclusive teaching. In his influential book Learning Styles and Inclusion educational psychologist Gavin Reid states: 'In the climate of inclusion an understanding of how children learn, and of learning styles, is not only desirable, but essential' (Reid 2005:ix-x). In a similar vein, Danish psychologist Alenkær (2009) encourages teaching differentiation, claiming that inclusion regards all children: 'in the integration view of human nature some are more "normal" than others. In the inclusive view of human nature, no one is more normal than others. Everybody is special' (p. 20).

With the statement that 'everybody is special', Alenkær rejects the idea that special needs only concerns a minority. Inclusive teaching becomes a matter of preparing individualized teaching for all pupils, regardless of whether their special needs concern learning challenges or special talents. His view, in this sense, resembles that of the municipal director depicted above. 
The Danish teacher education was reformed in 2012. The reform adopted a view of special needs as a point of focus for a general differentiated pedagogy rather than a problem for many specialized pedagogies. The reform closed down special needs education as a separate subject while it integrated some aspects in other mandatory subjects (Ministeriet for Forskning, Innovation og Videregående Uddannelser, 2013). While the idea was to strengthen inclusion, researchers and practitioners have criticized the reform for watering down expertise in special needs education (Mainz, 2014). A tension emerges between the conviction that some teachers need special expertise in pedagogy for authentic special needs versus the view that inclusive special needs education is primarily about teaching differentiation.

While some Danish scholars suggest that the distinction between special needs education and general pedagogy has become blurred (Kristensen 2012, p. 52), others, such as Lotte Hedegaard-Sørensen (2013), aim to solve the tension with the term 'inclusive special needs education'. According to this concept, teachers are both to explore their teaching practice through 'practice narratives' and utilize 'scientific knowledge' about diagnoses.

Hedegaard-Sørensen's approach is interesting in terms of how it articulates the modern distinction (Latour, 1993). The distinction between human nature and social environment remains intact, yet knowledge from both poles can help the teacher. Whereas nature (authentic special needs) is represented through 'scientific knowledge', for instance, about how to organize teaching for pupils diagnosed with ADHD, 'practice narratives' represent the cultural and social side of the modern distinction. These narratives enable reflection on how the particular organization of a social learning environment may exclude pupils needing an ADHD-friendly learning environment. Put briefly, knowledge deemed to speak for human nature can instruct the organization of teaching whereas narratives deemed to speak for the social environment can question the teacher's assumptions and practices in organizing the very same teaching.

Educational psychologists also challenge the purified (social) version of special needs. Today, educational psychologists draw on a wide arsenal of technologies and tests, ranging from updated versions of the intelligence test, social constructionist methods that intervene in the social organization of learning environments, to tools for diagnosing ADHD and autism. 
The following excerpt from an interview with a managing educational psychologist illustrates the tensions of inclusion.

In our municipality, we have this paradigm to work relationally [with inclusion]. We need to look at children 'in challenging situations', not children 'with challenges'. This is repeated over and over and over. If we investigate the child as a problem, then it is stigmatization. But sometimes this is a necessary precondition for including the child (...) we have tried finding a child of low intellectual capacity in the seventh grade who hasn't benefited from his teaching in perhaps five years because we worked with the context. We were thinking, 'well, his behaviour is probably an expression of the context' and then we worked with improving the tone of the teaching and such. (...) but the behavioural problems grew and in reality they indicated that for five years, he didn't understand much of the teaching. We risk losing sight of the individual with the context-based perspective [of inclusion]. So we continue to use intelligence tests but they never stand alone.

(Interview with managing educational psychologist in [anonymous] local government, Denmark, 2013)

In the practical work of educational psychologists, different forms of knowledge, tests and methods present respectively the child's innate learning dispositions and the social environment as the object of intervention. In her view, the two versions of special needs can be accommodated when knowledge of the former is used to change the latter. However, due to a strong political focus on inclusion, in the local government where she is employed such combination is not always possible, resulting in alternations between the two instead, she explained.

Juxtaposing the current tensions with the settlement achieved through intelligence testing, we find some interesting continuities. First, the very distinction between human nature and social environment inadvertently seems to produce tensions: it is simply practically impossible to separate human nature from social environment, but the idea that it is or should be possible has many ramifications. While the early educational psychologists could not measure a pure, uncontaminated intelligence, contemporary educational psychologists try to take into account individual pupils' special needs even though this approach may be stigmatizing.

An interesting continuity regards educational psychologists' reflections on the status of the intelligence test vis-a-vis the organization of teaching. Both Henning Meyer in the 1930es and the educational psychologist I quoted above emphasize a holistic approach in which the intelligence test should never be the only basis for assessment. 
While Danish scholars ascribe Meyer a crucial role in introducing intelligence testing into the Danish school system (e.g. Ydesen, 2011), he did not do so uncritically. Meyer was also a pioneer advocate for teaching differentiation, even if this is commonly considered a more recent phenomenon. The intelligence test had a much more prevalent role in segregating pupils than scientific methods in contemporary inclusive education. Nevertheless, there seems to exist some curious continuities in the reflections and recommendations that respectively intelligence testing and inclusion give rise to.

\section{Conclusion}

In this paper, I have explored how two conceptions of special needs enact differently the modern distinction between human nature and social environment. With an ANT approach and especially by drawing on and Latour's (1993) diagnosis of the modern constitution I have explored settlements of this issue in special needs education. I juxtaposed the writings of primarily Danish educational psychologist Henning Emil Meyer, who introduced intelligence testing in Denmark to systematize segregated education and statements made by contemporary Danish psychologists. To explore the contemporary case, I have also analysed policy documents and interviews about inclusive education. ANT helped me analyse how the association of different techniques, semiotic articulations, and human actors enacted particular conceptions of special needs. Acknowledging, in Latour's words (1993, p. 141) the 'nonseparability of the common production of societies and natures', allows to keep in view the hybridity of both versions of special needs and their associated tensions.

First I analysed the conception of intelligence as innate, looking at articulations of intelligence and scholastic tests, ideas of pure intelligence, entrepreneurial teachers who could speak with the authority of a particular psychological expertise, mobilizing pupil bodies who could be sorted by new tests. This network enacted a distinction between a congenital intelligence, which could not be changed, and scholastic skills, which were seen as the result of education. With this distinction in place, teachers and educational psychologists could grant children the 'right' education. Children with a low IQ and bad scholastic test results could be segregated to remedial education. If the test showed children to have a high IQ, this could trigger an investigation of potential social reasons for their low scholastic results. 
The intelligence tests and scholastic tests were seen as representative of respectively the child's human nature (innate intelligence) and education (acquired skills). This separation legitimized a segregated educational system in which only some children were given the benefit of doubt. Yet, tensions emerged as the pure measurements that the intelligence test was imagined to provide proved practically impossible to achieve. The educational psychologists and teachers who promoted the intelligence test as the baseline for sorting pupils also considered factors such as children's efforts and endurance central to how pupils performed.

The contemporary educational policy of inclusion to some extent reverses cause and effect between human nature and social environment. Emerging with a heterogeneous network (Callon, 1987) of statistics, policy, and new knowledge institutions, this settlement problematizes teachers' categories for their stigmatizing effects. The modern settlement is still powerful in organizing special needs education, the emphasis now being on how professionals organize the educational environment.

Tensions here include how to take seriously a medical view of authentic special needs requiring specialized treatment when the very act of diagnosis is seen as problematic and stigmatizing. Instead of increased segregation, inclusion entails encounters of many different versions of special needs: special needs as a cultural expression of categories, values and mindsets; special needs as regarding all children and not just a minority ('everybody is special'); special needs as a psycho-medical condition that can be helped through inclusive teaching.

While the last part of the analysis in this paper focused on a social constructivist version of special needs, it is important to note that the concept of special needs remains controversial beyond this perception. New conceptions and techniques will continue to contribute to its make-up and challenge the organization of special needs education. Currently, the proliferation of new psychiatric diagnoses such as ADHD and diagnoses within the spectrum of autism challenge the social constructivist view of special needs connected to inclusion.

Different versions of special needs are results of particular epistemic practices that bring special needs into being as particular objects of intervention. Hence, engaging with special needs today is a matter of managing its many versions rather than settling on one over another (Mol, 2002). What counts as special needs is ambiguous and 
special needs can neither be singularized nor stabilized. This reminds us of how important it is to continuously explore how society and human nature become entangled, separated and to repeatedly re-imagine how we know our biological-social bodies.

Latour emphasizes that making 'explicit' hybridization will challenge purification and allow for non-modern forms of intervention (Latour, 2003, 40). My analysis suggests something else. The 'discovery' that special needs are not simply objective facts waiting to be revealed by tests but are entangled in cultural frameworks has not lead to a 'shared responsibility for action' or a 'restored symmetry' between nature and humanity (Latour, 1993, 54). Instead we see a move from naturalization to resocialization where new asymmetries arise. These effect new attributions of responsibility and possibilities for action among humans, deemed to have the potential to change their cultural constructions through reflection.

My juxtaposition of the two moments in history of special needs education illustrates how special needs bounce between the two poles of a modern distinction between human nature and social environment, generating practical tensions for both conceptions. This speaks to the relevance of exploring empirically how modern nature/culture bifurcations develop in other subject matters. Instead of speculating on a general fate of the 'moderns' and purification (Latour, 2003, p. 40), my hope is that this case study of special needs education may inspire specific elucidations of the surprising ways in which modern settlements emerge and endure. What may appear as its demise may in fact reinforce it, exchanging one set of asymmetries with another.

\footnotetext{
${ }^{\mathrm{i}}$ In England, a similar widening of the concept was introduced in 1978 with the English Warnoch Report, which introduced the term special needs education to replace the term special education. It advocated schools to offer special needs education to 'all pupils who could not follow the ordinary teaching, regardless of the kind or cause of these difficulties' and estimated that approximately $20 \%$ of all pupils needed this support. Depicting this report as an important moment facilitating the widespread special needs education in Denmark, the Danish Ministry of Finance in 2010 commented that 'Denmark followed this development' (Danish Ministry of Finance, 2010, p.40).

ii This translation from Danish to English, as well as all following quotations that are listed with Danish references in the bibliography, were made by the author.

${ }^{\text {iii }}$ While Binet in his original test divided children into their so-called 'intelligence age' - i.e. a 10 year old could figure with an intelligence of an eight year old - Meyer took his inspiration from the German psychologist William Stern who related the intelligence age to the biological age (IA/BA*100), giving
} 
the result in 'intelligence quotient' (IQ). For Meyer, the IQ offered a more precise scale as it was far more serious to lack behind with two years of intelligence as a six year old than as an eight year old (Meyer, 1929, 697).

\section{Acknowledgements}

[please paste from cover letter]

\section{Bibliography}

Ainscow, M. (1995) Special needs through school improvement: School improvement through special needs. In C. Clark, A. Dyson and A. Millward (Eds.), Towards inclusive schools?, pp. 63-77 (London: David Fulton).

Alenkær, R. (2009) Den inkluderende skole - i et ledelsesperspektiv. Copenhagen: Frydenlund.

Andersen, J. (2009) Forstærker fagfolk selv nogle af de problemer, de er sat til at løse? In Alenkær. R. (ed.) Den inkluderende skole - $i$ et ledelsesperspektiv, pp.157-181. (Copenhagen: Kroghs Forlag).

Avramidis, E. \& Norwich, B. (2002) Teachers' attitudes towards integration/inclusion: A review of the literature. European Journal of Special Needs Education, 17(2), pp. 129-147.

Barton, L. (Ed.). (1987) The politics of special educational needs (Lewes: Falmer Press).

Bendixen, C. (2008) Hvordan intelligenstestningen kom ind i folkeskolen - og blev der. Dansk Padagogisk Tidsskrift, 9(3), pp. 14-23.

Binet, A., Simon, T. \& Drummond, W. B. (1914) Mentally defective children. (London: Edward Arnold).

Brown, S. (2010) Between the planes: Deleuze and social science. In C. B. Jensen, and K. Rödje (Eds.), Deleuzian intersections: Science,technology and anthropology (Oxford: Berghahn Books).

Callon, M. (1986) Some elements of a sociology of translation: Domestication of the scallops and the fishermen of st brieuc bay. In J. Law (Ed.), Power, action and belief: A new sociology of knowledge?, pp. 196-223 (London: Routledge).

Callon, M. (1987) Society in the Making: The Study of Technology as a Tool For Sociological Analysis. In W. Bijker, T. Hughes \& T. Pinch (eds.) The Social Construction of Technological Systems. (Cambridge: MIT Press). 
Callon, M. (2008) Economic markets and the rise of interactive agencements: From prosthetic agencies to habilitated agencies. In T. Pinch and R. Swedberg (eds) Living in a material world pp. 29-56. Cambridge, MA: The MIT Press.

Coninck-Smith, N. (2000) For barnets skyld - byen, skolen og barndommen 18801914 (Copenhagen: Gyldendal).

Conrad, P. (1975). The Discovery of Hyperkinesis: Notes on the Medicalization of Deviant Behavior. Social Problems, 23(1), pp. 12-21.

Danish Ministry of Education (2003) Skolens rummelighed - fra idé til handling (Copenhagen: Danish Ministry of Education).

Danish Ministry of Finance (2010) Specialundervisning i folkeskolen - veje til en bedre organisering og styring. (Albertslund: Rosendahls-Schultz Distribution).

Danish Ministry of Higher Education and Science (2013) BEK nr 231 ad 08/03/2013.

Egelund, N. (2004) Kunsten at kunne rumme børn og unge med særlige behov, In J. Andersen (Ed.), Den rummelige skole - et falles ansvar, pp. 37-58 (Vejle: Kroghs Forlag).

Galis, V. (2011) Enacting disability: how can science and technology studies inform disability studies?, Disability \& Society, 26(7), pp. 825-838

Hamre, B. (2012) Potentialitet og optimering i skolen. Problemforståelser og forskelssatninger af elever - en nutidshistorisk analyse. Doctoral dissertation, (Aarhus: University of Aarhus).

Hansen, J.H. (2012) Limits to inclusion. International Journal of Inclusive Education 16(1), pp. 89-98.

Hedegaard-Sørensen, L. (2013) Inkluderende specialpadagogik: Procesdidaktik og situeret professionalisme i undervisningen. Copenhagen: Akademisk Forlag.

Jensen, C.B. (2006) Experimenting with Political Ecology: Bruno Latour, 'Politics of Nature: How to Bring the Sciences into Democracy' by Bruno Latour. Review, Human Studies, 29, pp.107-22

Jensen, C.B. and Lauritsen, P. (2005) Reading digital Denmark: IT reports as material-semiotic actors, Science, Technology \& Human Values, 30(3), pp.35273.

Jydebjerg, C. \& Hallberg, K. (2006) Rummelighed og inklusion i folkeskolen. (Copenhagen: Center for Ligebehandling af Handicappede).

Kirkebæk, B. (2010) Almagt og afmagt-Specialpadagogikkens holdninger, handlinger og dilemmaer (Copenhagen: Akademisk Forlag). 
Kristensen, J.E. (2012) Viljen til inklusion - en samtidsdiagnostisk indkredsning. Dansk Paedagogisk Tidsskrift, 24(4), pp. 50-59.

Langager, S. (2004) Plads til forskellighed? - rummelighedens retorik. In J. Andersen (Ed.), Den rummelige skole - et falles ansvar, pp. 99-126 (Vejle: Kroghs Forlag).

Latour, B. (2005) Reassembling the Social: An Introduction to Actor-Network-Theory. (Oxford: Oxford University Press).

Latour, B. (2003) Is Re-modernization Occurring - And If So, How to Prove It? Theory, Culture \& Society, 20(2), pp. 35-48.

Latour, B. (1993 [1991]) We have never been modern. (Cambridge, MA: Harvard University Press).

Latour, B. (1991) Technology is society made durable. In j. Law (ed.) A sociology of monsters. Essays on power, technology and domination, Sociological Review Monograph 38, pp. 103-131. (London: Routledge).

Latour, B. (1987) Science in action: How to follow scientists and engineers through society.( Cambridge, MA: Harvard University Press).

Latour, B. (1983) Give me a laboratory and I will raise the world. In M. Mulkay, K. Knorr-Cetina (eds), Science observed, perspectives on the study of science, $\mathrm{pp}$. 141-170. (London: Sage).

Law, J. (1999) After ANT: Complexity, Naming and Topology. In J. Law and J. Hassard (eds) Actor Network Theory and after, pp. 1-15. Oxford: Blackwell Publishing/The Sociological Review.

Mainz, P. (2014) Lærere mister uddannelse i specialbørn, Politiken, http://politiken.dk/indland/uddannelse/ECE2231389/laerere-mister-uddannelse-ispecialboern/ (2014/12/18).

Maurer, B. (2005) Mutual life, limited: Islamic banking, alternative currencies, lateral reason (Princeton, New Jersey: Princeton University Press).

Meyer, H. (1926) Om standpunktsprøver, Vor Ungdom, 47, pp. 37-50.

Meyer, H. (1929) Børnepsykologien og dens Anvendelse i Danmark og England I, Folkeskolen, 46(39), pp. 681-683

Meyer, H. (1929) Børnepsykologien og dens Anvendelse i Danmark og England II, Folkeskolen, 46(40), pp. 697-700

Meyer, H. (1929) Børnepsykologien og dens Anvendelse i Danmark og England III, Folkeskolen, 46(41), pp. 713-718

Meyer, H. (1929) Børnepsykologien og dens Anvendelse i Danmark og England IV, Folkeskolen, 46(42), pp. 727-729 
Meyer, H. (1932) Psykologiske undersøgelser i det praktiske skolearbejdes tjeneste, Vor Ungdom, 53, pp. 385-402.

Meyer, H. (1943) Skolepsykologen arbejder, Folkeskolen, 60(34), pp. 603-604

Mittler, P. (2000) Working towards inclusive education: Social contexts (London: David Fulton).

Mol, A. (2002) The body multiple: Ontology in medical practice (Durham: Duke University Press).

Oliver, M. (1986) Social policy and disability: Some theoretical issues. Disability, Handicap and Society, 1(1), p. 5-18.

Ratner, H. (2012) Promises of reflexivity: Researching and managing inclusive schools. Ph.d. dissertation. (Copenhagen: Copenhagen Business School).

Reid, G. (2005) Learning styles and inclusion (London: Sage Publications).

Rose, N. (1998) Inventing Our Selves. Psychology, Power and Personhood (Cambridge: Cambridge University Press).

Sebba, J. \& Sachdev, D. (1997) What works in inclusive education? (Essex: Barnado's).

Singh, I. (2008). ADHD, culture and education. Early Child Development and Care, 178(4), pp. 347-361

Skrtic, T. M. (1991) The special education paradox: Equity as the way to excellence. Harvard Educational Review, 61(2), pp. 148-206.

Smith, D.E. 1978. 'K is mentally ill' the anatomy of a factual account, Sociology, 12 (1), pp. 23-53.

Søegaard, J. (1939) Hvad forstaar Skolen ved et tungt begavet Barn?, Folkeskolen, 56(23),pp. 413-416

Thomas, G., Walker, D. \& Webb, J. (1997) The making of the inclusive school (London: Routledge Falmer).

Thomas, G. \& Loxley, A. (2001) Deconstructing special education and constructing inclusion (Buckingham: Open University Press).

Tomlinson, S. (1987) Critical theory and special education. CSTME Journal, 7(2), pp. 33-41.

Tordrup, S.A. (1968) Nogle bemærkninger vedrørende effekten og værdien af specialundervisning i dansk. Skolepsykologi, offprint, pp.172-201. 
UNESCO (1994) The Salamanca Statement and Framework for Action on Special Needs Education (Paris: UNESCO).

Ydesen, C. (2011) The rise of high-stakes educational testing in Denmark (19201970). Doctoral dissertation, Aalborg University, 2011.

Zobbe, K., Madsen, L., Feilberg, A. V., Sørensen, H., and Ertmann, B. (2011) De mange veje: Følgeforskning til skoleudvikling vedrørende "mindre specialundervisning, styrket faglighed og фget rummelighed" (Copenhagen: Teori og Metodecentret, UCC).

\section{Biographical note}

Please paste from cover letter 